FisiPublik : Jurnal IImu Sosial dan Politik

https://journal.uwgm.ac.id/index.php/fisipublik

P-ISSN: 2528-2689; E-ISSN: 2540-9751

Vol 04 No 01 Mei 2019,

\title{
Dampak Pembangunan Malang Town Square (Matos) di Tinjau dari segi Hukum
}

\section{Administrasi Negara}

\author{
Kevin Herma Nadia ${ }^{1}$, Dewi Mufarihah ${ }^{2}$, Najmatul Ulla ${ }^{3}$ \\ 123Jurusan Administrasi Publik, Fakultas Ilmu Administrasi, Universitas Islam Malang \\ Email: Kvnhermanadia05@gmail.com, dfariha327@gmail.com, ema.najma98@gmail.com
}

\begin{abstract}
Abstrak
Kecenderungan untuk mengupayakan efektifitas komersil megakibatkan terjadinya pergeseran wadah bagi kegiatan perdagangan. Sehingga sistem seperti pertokoan linier (Shopping Street) maupun pasar tradisional perlahan mulai ditinggalkan, semua itu dialihkan dengan munculnya suatu pusat perbelanjaan modern yaitu mall. Yang tidak hanya menyediakan kelengkapan, kenyamanan, kemudahan serta efektifitas komersil yang tinggi. Kota malang merupakan kota yang dianggap seperti salah satu metrpolitan yang dapat disejajarkan dengan surabaya dan jakarta, tidak heran jika malang cukup banyak menjadi incaran para perusahaan untuk membangun sebuah pusat perbelanjaan yang besar sebagai sarana untuk memenuhi kebutuhan masyarakat dikota tersebut. Perancanagan pembagunan pusat perbelanjaan di kota malang berdasarkan pada konsep fungsi yang diwadahi kebijakan publik ditinjau dari lokasi pendiriannya yaitu di dekat bangunan edukasi maupun daerah resapan air menjadikan pro dan kontra atas pembangunan tersebut. Penelitian ini bertujuan untuk menggambarkan intervensi dampak yang yang ditimbulkan pembangunan pusat perbelanjaan Malang Town Square yang didirikan pada letak yang menjadi kontrofers dikalangan pelajar maupun masyarakat disekitar ditinjau dari hukum administrasi negara itu sendiri. Metode penelitian ini menggunakan metode diskriptif. Data yang digunakan diperoleh melalui penelusuran kepustakaan, pengamatan, dokumentasi yang relevan.

Keyword: Pembangunan Pusat perbelanjaan, Dampak Pembangunan, Hukum Administrasi Negara
\end{abstract}


FisiPublik : Jurnal IImu Sosial dan Politik

https://journal.uwgm.ac.id/index.php/fisipublik

P-ISSN: 2528-2689; E-ISSN: 2540-9751

Vol 04 No 01 Mei 2019,

The Impact of Development Malang Town Square (MATOS) in Terms of Laws Review Public Administration

\begin{abstract}
The tendency to strive for commercial effectiveness results in a shifting platform for trading activities. So that systems such as linear shopping (Shopping Street) and traditional markets slowly began to be abandoned, all of that was diverted by the emergence of a modern shopping center, the mall. Which not only provides completeness, comfort, convenience and high commercial effectiveness. Malang city is considered as one of the metropolitan cities that can be equated with Surabaya and Jakarta. It is not surprising that Malang is quite the target of many companies to build a large shopping center as a means to meet the needs of the people in the city. The development of shopping center development in Malang is based on the concept of function that is accommodated by public policy in terms of the location of its establishment, which is near the educational building and water catchment area, making the pros and cons of the development. This study aims to describe the impact interventions caused by the construction of the Malang Town Square shopping center which was established in a location that became a contributor among students and the surrounding community in terms of the country's administrative law itself. This research method uses descriptive method. The data used is obtained through searching literature, observing, relevant documentation.
\end{abstract}

Keyword: Shopping Center Development, Development Impact, State Administrative Law 
FisiPublik : Jurnal IImu Sosial dan Politik

https://journal.uwgm.ac.id/index.php/fisipublik

P-ISSN: 2528-2689; E-ISSN: 2540-9751

Vol 04 No 01 Mei 2019,

\section{Pendahuluan}

Dalam kehidupan masyarakat era modern ini mall telah menjadi simbol urbanisasi yang telah menjadi primadona masyarakat. Mall menjadi salah satu sarana untuk sesuatu yang sudah direncanakan seperti propertikebutuhan rumah tangga menjadi fungsi mall yang paling minimal. Selain itu mall juga berfungsi sebgai sarana berbeanja dan hiburan yang disatukan menjadi satu tempat.

Pusat perbelanjaan adalah seelompok bangunan komersil yang dibangun dan didirikan pada lokasi yang direncanakan, dikembangkan, dmulai dan diatur darisebuah kesatuan operasi, yang berhubungan dengan lokasi, ukuran, tipe toko, dan area perbeanjaan dari unit tersebut. Unit ini juga menyediakan parkir yang dibuat berhubungan dengan tipe dan ukuran total dari toko toko(Urban Land Institute.1977). Pusat perbelanjaan adalah tempat suatu tempat yang dijadikan sebagai tempat pertukaran dan distribusi barang maupun jasa yang bercirikan komersil. Melibatkan waktu dan perhitungan khusus dengan tujuannya adalah memetik keuntungan (Gruen. 1973). Maka secara global pusat perbelanjaan adalah suatu wadah yang dalam masyarakat yang menghidupkan kota atau lingkungan setempat selain sebagai tempat untuk kegiatan berbelanja atau transaksi jal beli juga sebagai tempat untuk berkumpul atau rekreasi (Bandngtoon. 1982).

Menurut Badan Perencanaan Dan Pembangunan Daerah Kabupaten Malang keadaan gegrafi kota malang terletak antara 440 - 667 meter diatas permukaan laut. Dengan suhu 22,5 18,5 derajad celcius, merupakan salah satu tujuan wisata jawa Timur karena potensi alam dan iklim yang dimiliki. Perekomian kota malang ditunjang dari beberapa sektor diantaranya industri, jasa, perdagangan dan pariwisata. Sebagai kota terbesar kedua di Jawa Timur, laju kota malang merupakan terpenting kedua setelah Surabaya.Oleh karena itu pendapatan perkapita kota Malang banyak didapatkan dari tempat perbelanjaan dan pariwisata yanga ada disana.

Perhatian yang tertuju pada gedung - gedung tinggi yang menjadi pusat perbelanjaan yang mencolok di kota Malang. Namun dalam pembangunan pusat perbelanjaan yang dibangun di kota malang banyak perusahaan yang menghiraukan AMDAL (Analisis Mengenai Dampak Lingkungan) yang seharusnya menjadi barometer pengkajian mengenai dampak besar dan penting suatu usaha/kegiatan yang direncanakan pada lingkungan hidup yang diperlukan bagi proses pengambila keputusan tentang penyelenggaraan usaha / kegiatan di daerah tersebut. 
FisiPublik : Jurnal IImu Sosial dan Politik

https://journal.uwgm.ac.id/index.php/fisipublik

P-ISSN: 2528-2689; E-ISSN: 2540-9751

Vol 04 No 01 Mei 2019,

Dilihat dari hal tersebut pembangunan Malang Town Square yang terletak didaerah resapan air dan dilingkukan pusat pendidikan dilihat dari kaca ata Hukum Administrasi Negara sangat tidak sesui dan menyalahi aturan yang ada beragai dampak akan muncul dari pembangunan tersebut. Yang seharusnya mall merupakan representatif berbagai paradok kehidupan masyarakat sosial.

\section{Metode}

Metode penelitian adalah proses mencari solusi gua untukmemecahkan suatu masalah yang sedang diteliti oleh peneliti dengan cara mendapatkan data. Metode penelitian berhubungan erat dengan prosedur, teknik, alat, seta desain penelitian yang akan digunakan. Metode yang digunakan dalam penelitian ini adalah metode deskriptif. menjelaskan bahwa " penelitian deskriptif dirancang untuk memperoleh informasi tentang status gejala saat penelitian dilakukan, peneitian ini digunakan untuk menerapkan sifat suatu situasi pada waktu penelitian itu dilakukan "(Furchan. 2011)

Bentuk penelitian yang digunkan disini adalah bentuk penelitian studi kasus, karena penelitian studi kasus adalah bentuk penelitian yang memusat pada suatu kasus secara intensif dan mendetail, objek yang diteliti terdiri dari satu unit kesatuan yang dipandang sebagai kasus dan objek kasus dalam penelitian ini adalah pendirian Malang Town Square (MATOS). Objek kasus dari penelitian ini adalah Malag Town Square pasca pembangunanya menimbulkan banyak pro dan kontra diberbagai kalangan. Dimana pendirianya terletak dipusat kota dan daerah aliran air serta daerah pendidikan. Untuk memperoleh data yang lengkap maka diperlukan teknikpengumpulan data yang tepat untuk memperoleh informasi kasus ini. Teknik pengumpulan data yang digunakan peniliti adalah dokumentasi, lalu dari perolehan data tersebut peneliti mengolah dan menganalisis dengan tahapan yang merujuk pada : identifikasi masalah, diagnosis, prognosis, pemberian solusi, evaluasi dan tindak lanjut.

\section{Pembahasan}

\section{Pembangunan Pusat Perbelanjaan Malag Town Square (MATOS)}


FisiPublik : Jurnal IImu Sosial dan Politik

https://journal.uwgm.ac.id/index.php/fisipublik

P-ISSN: 2528-2689; E-ISSN: 2540-9751

Vol 04 No 01 Mei 2019,

Malang Town Square merupakan salah stu mall besar di kota Malang. Mall ini didirikan pada pertengahan tahun 2005. Mall 4 lantai ini terletak di jalan Veteran kota malang. Tak begitu lazim ketika ada pusat perbelanjaan di daerah yang merupakan salah satu kawasaan pendidikan di kota Malang tersebut. Jalan Veteran merupakan serangkaian kawsan pendidikan di kota Malang. Banyak lembaga pendidikan yang berdiri sepanjang jalan tersebut. Mulai dari Universitas Negeri Malang yang gerbangnya tepat di depan bangunan Matos. DisisI timur UM ada kompleks Sekolah Terpadu yang berisikan Bustanul Athfal Restu, MIN 1 Malang, MTsN 1 Malang dan MAN 2. Sementara disisi barat UM ada SMA Negeri 8 Malang, SMP Negeri 4 Malang, dan SMK Negeri 2 Malang. Bahkan di ujung jalan Veteran ini berdiri tegak Kantor Dinas Pendidikan Kota Malang yang menegaskan jalan itu sebagai kawasan pendidikan di kota tersebut.

Malang Town Square yang merupakan salah satu pusat perbelanjaan terlengkap di Kota Malang yang mengusung konsep famliy mall yang menyediakan kebutuhan seluruh angota keluarga dalam satu tempat. Sebelum memulai dioperasikan pada tahun 2005, sebenarnya sempat mendapatkan penolakkan dari warga sekitar terutama beberapa lembaga pendidikan yang berada disekitar lokasi proyek pembangunan mall ini.

Pusat perbelanjaan yang merupakan keluarga besar jaringan Lippo ini terdiri dari 4 lantai dimana tiap lantainya menyediakan gerai-gerai yang menwarkan berbagai kebutuhan yang di perlukan Masyarakat.

\section{Dampak Pembangunan}

Dalam menghadapi pembangunan yang semakin komplek seperti Malang Town Square yang merupakan sebuah pusat perdagangan skala regional yang berdiri di tengah-tengah lingkungan sosial masyarakat yang mengakibatkan berkurangnya lahan produktif yang seharusnya di peruntukkan untuk menunjang kehiduppan ekosistem perkotaan. Keberadaan mall sering kali membuat pro kontra di antara banyak kalangan. Ada yang menganggap kehadiran mall sangat penting bagi perekonomian keluarga, sementara disisi lain kehadiran justru merugikan. Penelitian menurut Colliers Internasional Indonesia, Ferry Salanto mencoba menjelaskan untung rugi nya kehadiran bagi masyarakat."Mall di nilai positif karena potensi pengembangan ekonomi lebih terbuka. Kemudian arus investasi dari developer (pengembang) 
FisiPublik : Jurnal IImu Sosial dan Politik

https://journal.uwgm.ac.id/index.php/fisipublik

P-ISSN: 2528-2689; E-ISSN: 2540-9751

Vol 04 No 01 Mei 2019,

masuk". Disisi yang lain, keuntungan adanya mall adalah menggenjot penerimaan pendapatan asli daerah (PAD) dalam hal ini pemerintah daerah (Pemda)."Ada pajak untuk daerah da nada sebuah pusat perputaran uang yang cukup besar untuk Pemda. Kemudian salah satu peran penting mall adalah mendorong peningkatan konsumsi dalam negeri. Akan tetapi, kehadiran mall juga bisa berdampak negative, selain kemacetan fenomena gagal bayar kartu kredit menjadi sorotan akhir-akhir karena kuatnya daya beli masyarakat tanpa diimbangi pendapatan yang belum sesuai.

Besarnya pengaruh pembagunan mall disekitar bangunan pendidikan akan mengakibatkan dampak aspek fisik dan aspek non fisik. Pada dampak aspek fisik (mengarah pada lingkungan alam) bagi lingkungan sekitar diantaranya meliputi: banjir, polusi dan efek rumah kaca. Membahas masalah banjir otomatis bencana tersebut akan terjadijika tidak ditanggulangi secara baik dan efesien. Karena adanya pembangunan sebuah mall maka daya serap air berkurang. Banjir dapat dirumuskan sebagai berikut: Konsep banjir-Lintasan air \{air yang mengalir\}- kapasitas saluran\{debit selokan\}. Sehingga agar pembangunan berjalan lancar dan tidak berdampak banjir, maka pembangunan tersebut harus di minimalisasi sebaik mungkin agar daya penyerapan betul-betul dioptimalkan seperti dibangunnya selokan dekat pembangunan mall tersebut, karena kapasitasnya selokan dengan lintas air yang mengalir tidak sesuai dengan debet selokan yang ada sehingga air meluap.

Tidak hanya banjir, polusipun akan berdampak akibat adanya pembangunan sebuah mall diantaranya Polusi udara, setelah adanya pembangunan mall otomatis wilayah tersebut akan lebih ramai karena masyarakat akan berbondong-bondong datang ke tempat tersebut sehingga jika hal itu terjadi pasti banyak kendara lalu lalang didaerah tersebut, akibatnya banyak asap yang dikeluarkan oleh kendaraan bermotor, karena hal itulah yang menyebabkan terjadinya Polusi Udara. Selain kedua hal diatas, juga bisa terjadi efek rumah kaca. Efek rumah kaca dapat terjadi apabila Polusi Udara yang terjadi berlebihan yang ditimbulkan oleh asap kendaraan bermotor yang menyebabkan udara panas. Selain itu sinar mataharitidak bisa diserapsecara lansung oleh tanah karena adanya paving di mall tersebut.

Ditinjau dari aspek non fisik (mengarah pada sosial) misalnya pergesaran budaya local atau kearifan local, dimana yang dulunya masyarakat bersifat bergotong royong, saling bahu membahu. Kini akibat adanya pembangunan mall, sikap masyarakat\{budaya masyarakat\} 
FisiPublik : Jurnal IImu Sosial dan Politik

https://journal.uwgm.ac.id/index.php/fisipublik

P-ISSN: 2528-2689; E-ISSN: 2540-9751

Vol 04 No 01 Mei 2019,

semakin hari semakin luntur dan berubah menjadi sikap induvidualisme terhadap sesame, sikap pemborosan atau suka berbelanja. Selain juga terjadi perubahan pada pola piker dan watak seseorang berubah misalnya terlihat lebih modern akibat barang-barangyang ada di mall tersebut. Selain Aspek diatas yang haru diperhatikan dalam perencanaan pembangunan antara lain:

1) Aspek Geomerfologi \{bentuk lahan $\}$

Bentuk lahan harus ditinjau dan dianalisa, bahwa daerah yang bersangkutan adalah daerah lahan variasi (karst) . Maka dari itu perlu adanya menganalisis lahan tersebut apakah lahan tersebut kaya sumber air atau tidak. Selain itu harus menganalisa data serap lahan terhadap air pada daerah padat penduduk. Mengingat kondisi lahan yang dibangun pusat perbelanjaan atau malang town square daya serap terhadap air sangatlah kecil sehingga perlu dibuat suatu serapan air agar tidak menjadi banjir lokal.

2) Aspek Hidrologi

Pelintasan air merupakan banyaknya air yang mengalir, sedangkan kapasitas saluran adalah debit selokan untuk menampung air maka untuk menghindari banjir pemerintah harus memiliki suatu konsep pembangunan yang berwawasan lingkungan dan selokan air dengan lintasan yang seimbang. Besarnya dampak perubahan akibat adanya mall

a) Berapa banyak jumlah masyarakat yang terkena dampak

Dampaknya tidak hanya dirasakan untuk masyarakat sekitar tetapi membangun bangunan yang multisektor juga mempengaruh pada daerah atau wilayah tersebut.

b) Jangka waktunya terjadinya dampak pembangunan tersebut

Dampaknya bisa dalam jangka waktu panjang, misalnya ada dampak sosial, budaya, ekonomi yang telah dibahas. Dampak ini terjadi secara significant artinya aktifitas proyek akan mengganggu aktifitas masyrakat sekitar.

c) Intensitas dampak

Perubahan sosial, sifat fisik, konflik pro dan kontra. susunan lingkungan sekitar berubah. Masyarakat di wilayah jalan veteran pasti terkena dampak lingkungan pembangunan. tetapi beberapa masyrakat diantaranya bisa merasakan manfaat dari pembangunan itu. Jumlah yang sama atau lebih yang bisa dirasakan manfaatnya akan mendukung proses terjadinya pelaksanaan pembangunan itu, dan dampaknya bisa saja dapat dipulihkan 
FisiPublik : Jurnal IImu Sosial dan Politik

https://journal.uwgm.ac.id/index.php/fisipublik

P-ISSN: 2528-2689; E-ISSN: 2540-9751

Vol 04 No 01 Mei 2019,

kembali juga tidak dapat dipulihkan. Rencana usaha adanya wilayah yang mengalami perubahan mendasar memerlukan waktu beberapa dekade kedepannya. Prakiraan dampak besar dan penting antara lain, Pada saat pembangunan menggangu aktivitas keseharian ,

a. Fasilitas transportasi, aktivitas ekonomi, struktur penduduk terganggu, ini akan terjadi pada :

b. Fase konstruksi $\rightarrow$ Mobilitas peralatan $\rightarrow$ kebisingan $\rightarrow$ debu $\rightarrow$ gangguan kenyamanan.

c. Fase pra konstruksi $\rightarrow$ Adanya pembebasan Lahan $\rightarrow$ pemindahan perumahan $\rightarrow$ perubahan pekerjaan.

d. Kendalah lahan yang dibebaskan harus berdasarkan kepemilikan pribadi masyarakat. Kesulitan mencari tempat tinggal adalah salah satu contohnya

i. Perubahan sosial yang diakibatkan oleh faktor demografis seperti pola penduduk, sektor umum, transportasi, da rasio kepemilikan lahan.

ii. Pandangan masyarakat membangun mall merupakan symbol dari kemajuan wilayah. Yang artinya akan terjadi penyerangan terhadap arsitektr kota, diamana mall saat ini menjelma sebagai landmark, kota baru yang benderang. Sedangkan keberadaan kota tua cenderung redup dan terabaikan

\section{Hukum Administrasi Publik}

L.J. Van Apeldoorn yang menafsirkan pengertian hukum administrasi negara sebagai segala keseluruhan aturan yang harus diperhatikan oleh setiap pendukung kekuasaan yang diserahi tugas pemerintahan tersebut. Jadi, dalam penafsiran ini, L.J. Van Apeldoorn menitikberatkan hukum administrasi negara lebih pada aturan atau norma yang mengatur kekuasaan negara itu sendiri.

Satu hal yang harus diperhatikan sebagaimana dijelaskan di atas adalah hubungan antara negara dan masyarakat itu hubungan yang istimewa. Karena itu, sesungguhnya HAN bukan hanya merupakan seperangkat aturan, tetapi harus mengatur pula hubungan istimewa tersebut. Hal tersebut sesuai dengan pendapat Logemann dan Utrecht yang melihat dan memaknai hukum administrasi negara sebagai seperangkat norma-norma yang menguji hubungan hukum istimewa yang diadakan untuk memungkinkan para pejabat administrasi negara melakukan tugas mereka 
FisiPublik : Jurnal IImu Sosial dan Politik

https://journal.uwgm.ac.id/index.php/fisipublik

P-ISSN: 2528-2689; E-ISSN: 2540-9751

Vol 04 No 01 Mei 2019,

yang khusus. Pendapat ini didukung oleh J.M. Baron de Gerando yang menyatakan bahwa objek hukum administrasi adalah hal hal yang secara khusus mengatur hubungan timbal balik antara pemerintah dan rakyat sehingga titik berat objek HAN ada pada hubungan istimewa tersebut sehingga perlu ada dalam norma peraturan. Hukum administrasi negara memiliki ciri-ciri khusus yang meliputi:

a. adanya hubungan istimewa antara negara dan warga Negara.

b. adanya sekumpulan norma yang mengatur kewenangan pejabat atau lembaga Negara

c. adanya pejabat-pejabat negara sebagai pelaksana dari perjanjian istimewa tersebut.

Ruang lingkup hukum administrasi negara sesungguhnya sangat luas cakupannya. Hal itu sebagaimana diungkap oleh Prajudi Atmosudirdjo yang mengatakan bahwa ruang lingkup hukum administrasi negara meliputi:

1. hukum tentang dasar-dasar dan prinsip-prinsip umum administrasi negara;

2. hukum tentang organisasi administrasi negara;

3. hukum tentang aktivitas-aktivitas administrasi negara yang bersifat yuridis;

4. hukum tentang sarana-sarana administrasi negara, terutama kepegawaian negara dan keuangan negara;

5. hukum administrasi pemerintahan daerah dan wilayah yang dibagi menjadi:

a. hukum administrasi kepegawaian,

b. hukum administrasi keuangan,

c. hukumadministrasi materiil,

d. hukum administrasi perusahaan negara,

e. hukum tentang peradilan administrasi negara.

Dalam hal ini dikaitkan dengan kasus yang ada pembangunan pusat perbelanjaan yang berada di kota Malang berdampak pada lingkungan fisik maupun non fisik. Seperti halnya pada jumlah penduduk yang padat dan pembangunan gedung secara terus menerus yang mengharuskan ruang terbuka hijau banyak mengalami alih fungsi seperti dibangunnya ruko, perumahan, dan pusat perbelanjaan. Badan Perencanaan Pembangunan Daerah (BaPPeDa) harus lebih memperhatikan penataan ruang lingkup suatu bangunan mengingat RHT di Malang hanya sebesar $17 \%$ dari total luas wilayah yang mencapai $110 \mathrm{~km}$ tersebut. Hal tersebut tentu merupakan suatu pelanggaran terhadap UU No.26 Tahun 2007 tentang luas RHT di wilayah 
FisiPublik : Jurnal IImu Sosial dan Politik

https://journal.uwgm.ac.id/index.php/fisipublik

P-ISSN: 2528-2689; E-ISSN: 2540-9751

Vol 04 No 01 Mei 2019,

perkotaan yang seharusnya $30 \%$ minimal dari total luas wilayah yang ada, yang pembagiannya $20 \%$ RHT dan 10\% untuk alokasi RHT private. Beberapa kaum intelektual maupun LSM sudah melakukan berbagai protes terkait alih fungsi RHT ini, namun Pemkot Malang tidak memberikan tanggapan walaupun ada upaya dari kaum tersebut untuk mempertahankan Perda Nomor 4 tahun 2011.

Pihak pemerintah yang membiarkan pusat perbelanjaan ini berdiri, sehingga memicu dibangunnya pusat perbelanjaan lain yang berada di kawasan RHT. Jika dilihat dari hukum administrasi publik dimana fungsi dari hukum tersebut untuk mengatur dan menjadi payung hukum dalam kebijakan suatu daerah dimana tujuannya adalah untuk memperbaiki dan meningkatkan kesejahteraan masyarakat serta menciptakan inovasi didalam masyarakat tersebut, dengan mata telanjang pemerintah Kota Malang kurang mengimplementasi dan mengakumulasikan UU dan Perda yang sudah dibuat. Dimana implementasi kebijakan publik ini merupakan suatu wujud tindakan pemerintah dalam mengatasi masalah yang timbul dalam masyarakat. Dan kebijakan ini dipandang sebagai proses perumusan kebijakan yang diimplementasikan dan dilaksanakan dalam wujud nyata.

Kebijakan implementor dalam penataan tata ruang pembangunan gedung serta pusat perbelanjaan di Kota Malang tidak sesuai dengan peraturan yang ada, hal ini tentunya sangat berpengaruh dengan mobilitas serta kondisi fisik dan non fisik. Meskipun kasus ini sudah lama menggantung dalam hal perizinan pembangunan (IMB) pihak Malang Town Square telah memverikasi bahwa pihaknya telah mengusahakan dan meminta Dinas Perhubungan Kota Malang untuk memperoleh dan mengantongi IMB tersebut atau AMDAL Lalin.

\section{Kesimpulan}

Pembangunan tanpa memperhatikan AMDAL akan berdampak buruk pada lingkungan dan masyarakat, Implementor kebijakan publik harus lebih memperhatikan dan mengimplementasikan UU dan Perda yang ada, Pemerintaah harus lebih mementingkan kepentigan publik daripada kepentigan skateholders. Pemerintah harus lebih tegas terhadap pelaku pelanggaran pembangunan, Pemerintah seharusnya memperketat peraturan yang ada. Implementor secara konseptual harus melibatkan masyarakat semaksimal mungkin untuk memadukan perencanaan yang ada. Implementor tidak maksimal mengimplementasi 
FisiPublik : Jurnal IImu Sosial dan Politik

https://journal.uwgm.ac.id/index.php/fisipublik

P-ISSN: 2528-2689; E-ISSN: 2540-9751

Vol 04 No 01 Mei 2019,

perencanaan pembangunan seperti konsep yang dikembangkannya sendiri. Nilai positif karena potensi pengembangan ekonomi lebih terbuka. Arus investasi dari developer (pengembang) masuk". Disisi yang lain, keuntungan adanya mall adalah menggenjot penerimaan pendapatan asli daerah (PAD).

\section{Daftar Pustaka}

Hayat, Dkk. (2018). Reformasi Kebijakan Publik prespektif Makro dan Mikro. Malang: PRENADAMEDIA GROUP

Moleong, Lexy J. (2001), Metode Penelitian Kualitatif, cetakan keempatbelas, Bandung: PT Remaja Rosdakarya (anggota IKAPI).

Sugiono. (2005). Metode Penelitian Administrasi. Bandung: PT. Alfabeta

Sugiyono. (2006). Metode Penelitian Kuantitatif Kualitatif dan R\&D. Bandung: Alfabeta

Lailiyah, Nadia, 2005, “Aspek Pembangunan Malang Town Square Dan Dampaknya Terhadap Lingkungan Sosial Masyarakat (Studi Deskriptif pada Masyarakat Sekitar Kelurahan Penanggungan Kecamatan Klojen Kota Malang) ”, Journal Of Public Administration. 